\title{
Malnutrition Featured During the Nigerian Civil War as both Classical Kwashiorkor and Nascent Paragonimiasis
}

\author{
Onuigbo $\mathrm{W}^{*}$ \\ Department of Pathology, Medical Foundation and Clinic, Nigeria
}

*Corresponding author: Onuigbo W, Department of Pathology, Medical Foundation and Clinic, 8 Nsukka Lane, Enugu 400001, Nigeria, Email: wilson.onuigbo@gmail.com

Citation: Onuigbo W (2016) Malnutrition Featured During the Nigerian Civil War as both Classical Kwashiorkor and Nascent Paragonimiasis. J Gastroenterol Compl 1(1): 102

Received Date: July 15, 2015 Accepted Date: November 05, 2016 Published Date: November 09, 2016

\begin{abstract}
During the Nigerian Civil War, the world community became aware of the deaths due to classical Kwashiorkor. However, the purpose of the present paper is to reveal that there was the hitherto unknown concomitant malnutrition disease due to paragonimiasis, this being due to eating poorly cooked crabs because of the stresses of war time.
\end{abstract}

Keywords: Malnutrition; Kwashiorkor; Paragonimiasis; Civil war; Nigeria

\section{Introduction}

Kwashiorkor, a classical malnutrition disease [1], occurred during the Nigerian civil war in the dwindling enclave called Biafra [2]. This was the situation in which common crabs [3], played an uncommon role. Thus, as Nature has it, crabs actually provide secure homes for these perilous parasites which develop within them. It was the hapless eating of these that led to the development of a debilitating disease known as paragonimiasis. In other words, these parasitic dwellers are the normal offsprings of the adult worms named as Paragonimus uterobilateralis [4]. Accordingly, the relevant aspects of it that are poignantly distinguishable will be viewed from three dimensions consisting of (i) strict starvation, (ii) crab crunching, and (iii) perilous paragonimiasis!

\section{The civil war situation}

The stark scene of sorrowful suffering was set rather inexorably in that diminishing territory that the secessionist enclave became because of planned blockade by the Federal Army. In fact, it came to such a sorry stage that hungry families quickly subsisted by eating the common crabs [5]. Unfortunately, the hostile prevailing wartime circumstance was famishing. Moreover, there was such inadequate domestic incapacitating negligence that poor cooking of the diseased crabs arose. As a result, the paragonimus parasites, which were sojourning naturally inside these crabs, were still very much alive when they gained ready entrance into the bodies of the unfortunate hordes who were refugees in their own country.

\section{The post-war situation}

With the return of peace, an astute indigenous scientist, Prof. Chukuedu Nwokolo [6], surfaced at the Enugu General Hospital. His consultancy there and his wide reputation facilitated his contact with crowds of satisfied patients. Consequently, this was what enabled him to recognize the difference between (a) the few paragonimus patients whom he had seen personally prewar and (b) the postwar epidemic throng. Interestingly, laboratory investigation of the sputum revealed the presence not of the expected tuberculosis germs but of the specially shaped paragonimus eggs.

Eggs endowed with this particular shape abounded and were being documented thoroughly [7]. Interestingly, the adult egg-laying worms had never been identified within human beings. Little wonder that, as things stood in 1972, the puzzled Professor sought my help when, by that time, I was the Specialist Pathologist in charge of the Eastern Nigerian Regional Laboratory based at Enugu. He was the one who told me to be on the lookout for the hitherto hidden adult worms.

Worms being sought scientifically in this manner were to surface in the fullness of time. The full story was told in the 1974 September Issue of the bilingual English-German Journal called Tropenmedizin und Parasitologie [8], the terse title being "Discovery of Adult Parasites of Paragonimus uterobilateralis in Human Tissue in Nigeria" (Figure 1 and 2).

Nigeria in this way entered the exotic literature of food-borne Parasitology. However, this came largely to light after the war had ended. Therefore, by inference, there was malnutrition not only of the Kwashiorkor type but also of Paragonimiasis itself. Incidentally, on the saving grace was Prof Nwokolo who treated them successfully with the drug, Bithionol [9], and acknowledged its generous supply from the Center for Disease Control, Atlanta, Georgia, U.S.A. and the U.S.A.I.D. Tuberculosis Program. 


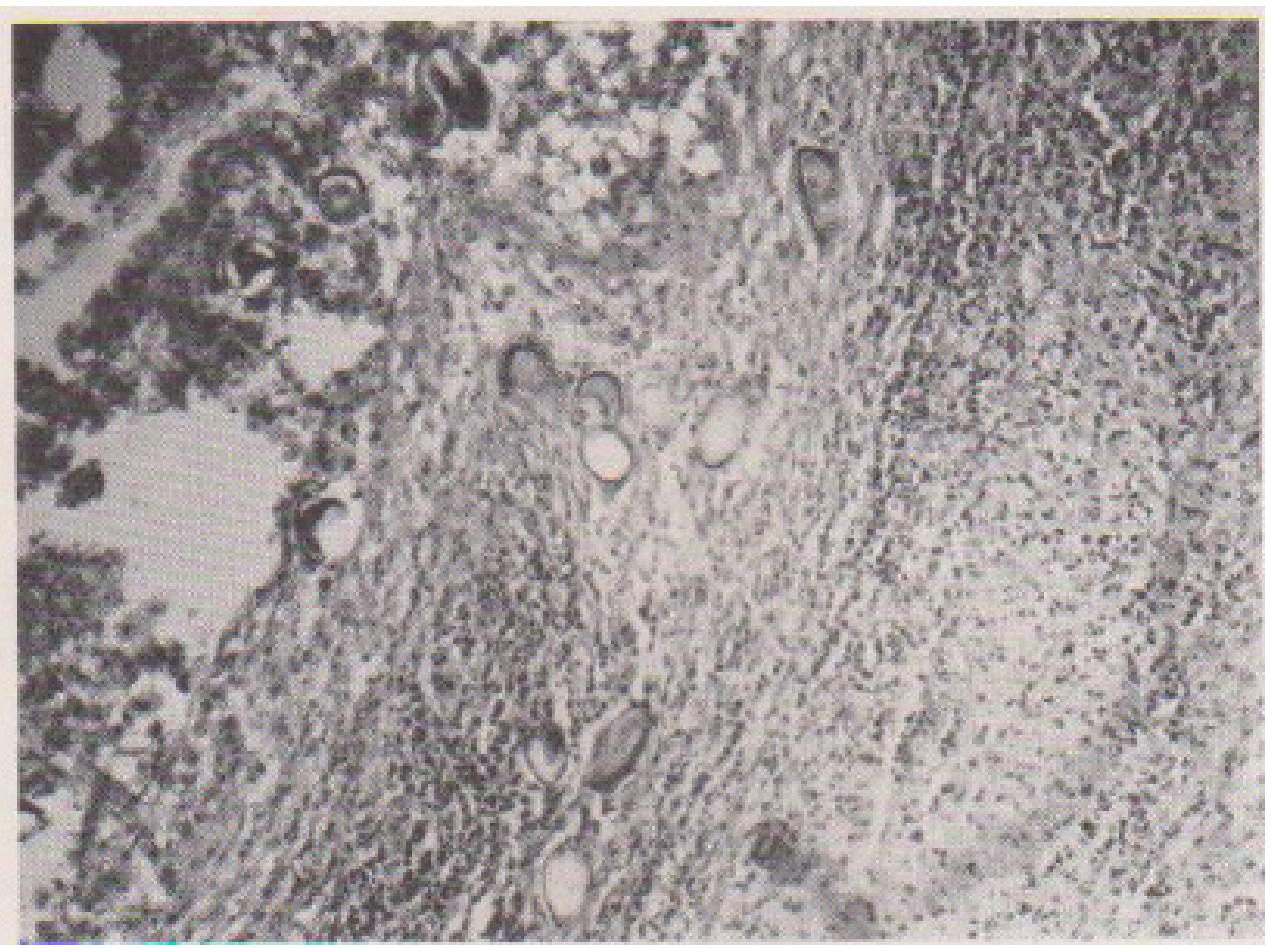

Figure 1: Section of wall and lumen of Paragonimus cyst, showing cyst wall and cellular debris in the cyst lumen. Parasite ova are numerous within the cyst wall and lumen.

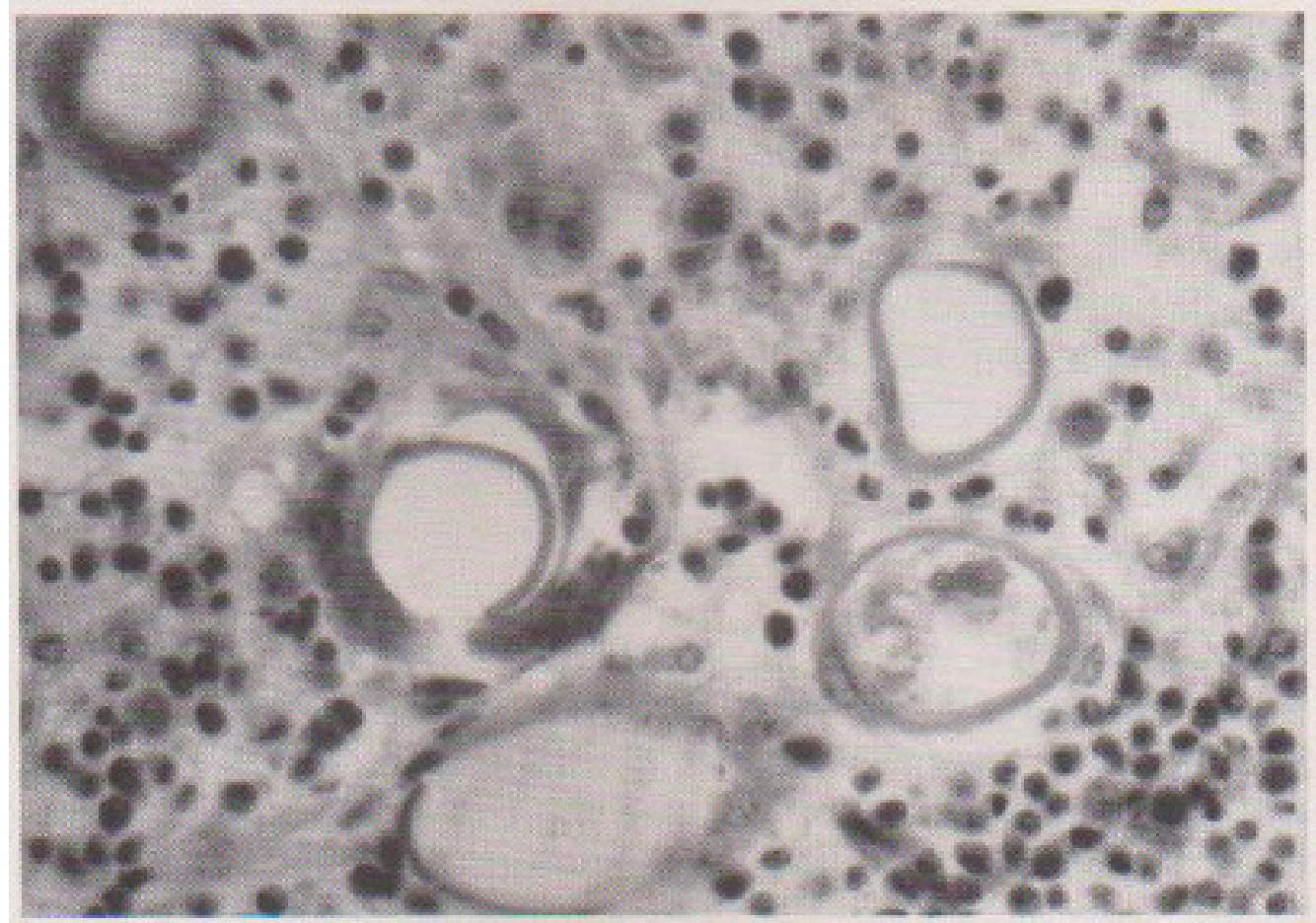

Figure 2: Parasite ova in the cyst wall, surrounded by round cells, histiocystes and epithelioid cells. Phagocytosis of an ovum by a mulcinucleated giant cell

\section{Discussion}

I am persuaded that this positive international assistance was one important and noteworthy aspect of the Nigerian Civil War. However, it actually covered a mere fraction of the populace, namely, the lucky victims who were treated successfully at Enugu. It did not apply to the rest of the exposed population who were also at risk. As reason must have it, this means that the very wellknown deaths due to kwashiorkor did not constitute the whole malnutrition picture. In other words, other unknown deaths must have occurred on account of paragonimiasis! In all probability, if sociological research is carried out now in the area, the findings could, with some accuracy, still unravel the degree of the unknown deaths attributable to paragonimiasis. At least, this will pave the way to appreciating that the secessionist patients were examples of the global burden of food-borne worm-induced disease [10]. Perhaps, the need for enthroning peace worldwide has been reinforced by this localized, unfortunate, war episode. 


\section{References}

1. Adams ARD, Maegraith BG (1964) Clinical Tropical Diseases ( $3^{\text {rd }}$ Ed) Oxford: Blackwell Scientific Publications 259.

2. Achebe C (2012) There was a country Allen Lane London.

3. Nwokolo C (1974) Endemic Paragonimiasis in Africa. Bull Wld Hlth Org 50: 569-71.

4. Ochigbo SO, Ekanem EE, Udo JJ (2007) Prevalence and intensity of Paragonimus uterobilateralis infection among school children in Oban village, South Eastern, Nigeria. Tropical Doctor 37: 224-6.

5. Udonsi JK (1987) Endemic Paragonimus infection in Upper Igwun Basin, Nigeria: a preliminary report on a renewed outbreak. Ann Trop Med Parasitol 81: 57-62.

6. Nwokolo C (1972) Outbreak of Paragonimiasis in Eastern Nigeria. The Lancet 299: 32-3.

7. Aka N'DA, Koffi A, Daniel R, Gilles D (2008) Human paragonimiasis in Africa. Ann African Med 7: 153-62.

8. Onuigbo WI, Nwako FA (1974) Discovery of adult parasites of Paragonimus uterobilateralis in human tissue in Nigeria. Tropenmed Parasitol 25: 433-6.

9. Hamajima F (1973) Studies on Metabolism of lung fluke genus paragonimus.VII. Action of Bithionol on glycolytic and oxidative metabolism of adult worms. Exp Parasitol 34: 1-11.

10. Furst T, Keiser J, Utzinger J (2012) Global burden of human food-borne trematodiasis: a systematic review and meta-analysis. The Lancet Infect Dis 12: 210-21. 